\title{
Effect of Cyclosporin A Treatment on the Production of Antibody in Insulin-dependent (Type I) Diabetic Patients
}

\author{
C. Boitard, * G. Feutren, ${ }^{*}$ L. Castano, ${ }^{*}$ M. Debray-Sachs, ${ }^{*}$ R. Assan, ${ }^{\ddagger}$ J. Hors, ${ }^{5}$ and J. F. Bach* \\ *Institut National de la Santé et de la Recherche Médicale (INSERM) U 25 and Centre National de la Recherche Scientifique (CNRS) \\ LA 122, Hôpital Necker, 75743 Paris, Cedex 15, France; ${ }^{\ddagger}$ Service de Diabétologie, Hôpital Bichat, 75018 Paris, France; \\ and ${ }^{\S}$ Hopital Saint Louis, 75010 Paris, France
}

\begin{abstract}
Anti-islet cell and anti-insulin antibody production was studied over a 12-mo period in 82 recently diagnosed diabetics randomly receiving either cyclosporin or placebo. Cyclosporin had only minimal effects on the production of anti-islet cell antibodies whether directed to islet cytoplasmic (immunofluorescence) or membrane (cytotoxicity assay) antigens even in patients undergoing remission. These data suggest that these antibodies do not play a major role in the pathogenesis of the disease particularly since their (irregular) presence is not predictive of the clinical response to cyclosporin. Conversely, cyclosporin completely suppressed the synthesis of antibodies elicited by exogenous insulin irrespective of the insulin doses received, and decreased the autoantibody production against thyroid antigens, indicating that cyclosporin has variable effects on antibody production against various antigens.
\end{abstract}

\section{Introduction}

Cyclosporin A has recently been shown to increase the length and rate of remissions in insulin-dependent diabetes mellitus (IDDM) $)^{1}(1-3)$. This major therapeutic breakthrough, which confirms in man similar data previously reported in rodent models (BB rat, NOD mouse) (4-7), brings strong support for an autoimmune origin of IDDM. Such an autoimmune nature has already been strongly suggested by several lines of evidence. Anti-islet cell antibodies are commonly observed at an early stage of the disease $(8,9)$. In Caucasian populations, IDDM has been shown to associate with HLA-DR3 and/or DR4 antigens (10). Evidence that cell-mediated immunity has a major involvement in the lesion of the insulin-producing $\beta$-cell has been obtained from the high proportion of T lymphocytes observed in the cellular infiltrate within the islets of Langerhans in recent onset IDDM (11-13), from the capacity of purified $\mathrm{T}$ lymphocytes to inhibit insulin release by islet

Address correspondence and reprint requests to Dr. Boitard, INSERM U 25 and CNRS LA 122, Hôpital Necker, 75743 Paris, Cedex 15, France.

Received for publication 27 January 1987.

1. Abbreviations used in this paper: AIA, anti-insulin antibodies; CFICA, complement-fixing islet cell antibodies; $\mathrm{HbAl}_{c}$, hemoglobin $\mathrm{Al}_{\mathrm{c}}$; ICA, islet cell antibodies; IDDM, insulin-dependent diabetes mellitus; S-ICA, sensitized ICA.

J. Clin. Invest.

(C) The American Society for Clinical Investigation, Inc.

0021-9738/87/12/1607/06 \$2.00

Volume 80, December 1987, 1607-1612 cells in vitro $(14,15)$, and from the potential role of interleukin 1 in islet $\beta$-cell destruction $(16,17)$. Transfer experiments clearly point to a predominant role of $\mathrm{T}$ lymphocytes in the NOD mouse model for spontaneous IDDM (18).

The problem remains however of the existence of a significant percentage of cyclosporin-resistant patients, and more generally of the mode of action of cyclosporin in this indication. We report here studies aimed at determining the immunological effects of cyclosporin A in IDDM patients that contribute to resolve these questions. Importantly, since data obtained in this investigation were compared with control data collected in a placebo group randomized with the cyclosporin A group, conclusions can be drawn despite the difficult problem of interference with the spontaneous evolution of immunological parameters in IDDM.

\section{Methods}

Patients. 82 patients in whom diagnosis of IDDM was established according to the World Health Organization criteria (19) were included in this study. These patients represent a large and unselected sample of the previously reported French randomized double-blind trial (3). 42 patients received $7.5 \mathrm{mg} / \mathrm{kg}$ body wt per $\mathrm{d}$ in a single oral dose of cyclosporin in olive oil $(100 \mathrm{mg} / \mathrm{ml})$ for $6-12 \mathrm{mo} .40$ patients received placebo in the form of an equal volume $(0.075 \mathrm{ml} / \mathrm{kg}$ body wt) of olive oil for 6-12 mo. The dosage of either cyclosporin A or placebo was increased to $10 \mathrm{mg} / \mathrm{kg}$ and $0.01 \mathrm{ml} / \mathrm{kg}$ body wt per d, respectively, at $3 \mathrm{mo}$, in case of persistent insulin requirement, to obtain the metabolic control defined below. The treatment was interrupted after 6 mo in case of failure. Failure was defined as insulin requirement above $0.25 \mathrm{U} / \mathrm{kg}$ body wt per $\mathrm{d}$. Remission referred to decreased insulin requirement. Incomplete remission was defined as insulin requirement below $0.25 \mathrm{U} / \mathrm{kg}$ body wt per $\mathrm{d}$ to obtain a metabolic control defined by fasting glycemia below $7.8 \mathrm{mmol} / \mathrm{liter}$, postprandial glycemia below $11.1 \mathrm{mmol} /$ liter, and glycosylated hemoglobin $\mathrm{Al}_{\mathrm{c}}\left(\mathrm{HbAl}_{\mathrm{c}}\right)$ below $7.5 \%$. Normal value for $\mathrm{HbAl}_{\mathrm{c}}$ was $5.0 \pm 0.8 \%$ (2 SD). Complete remission was defined by fasting and postprandial glycemia, respectively, below 7.8 and $11.1 \mathrm{nmol} /$ liter; and $\mathrm{HbAl}_{\mathrm{c}}$ below $7.5 \%$ in the absence of exogenous insulin or oral hypoglycemic agents.

Islet cell antibody (ICA) determination (immunofluorescence). ICA were determined by indirect immunofluorescence on frozen sections of a human group $O$ pancreas using a fluoresceinated anti-human IgG serum (Wellcome Diagnostics, Dartford, England) as described by Bottazzo et al. (8). Complement-fixing ICA (CF-ICA) were determined on similar sections using a fluoresceinated anti-C3 serum (Dakopatts a/s, Glostrup, Denmark) (20). A technique using pretreatment of sera by aprotinin was performed as described by Elliott et al. (21) to determine sensitized ICA (S-ICA). Antibody titers were determined by serial $\log _{2}$ dilutions. The precision and accuracy of ICA determination using the same pancreas as that used in this study was previously evaluated by the standard curve under the code number 4 as part of the First International Workshop on the standardization of cytoplasmic ICA (22). Intraassay variation was $95.6 \%$ when determining S-ICA titers of 22 samples studied blind twice. The specificity and sensitivity of ICA 
determination were 98.75 and $69 \%$, respectively, using the same pancreas as that used in the present study.

Cytotoxic antibodies. Cytotoxic antibodies to beta cells were determined as previously described by Dobersen et al. (23). Rat islet cell suspensions were obtained from 8-wk-old Wistar rats using collagenase and dispase as previously described. Islet cells were washed and incubated at $37^{\circ} \mathrm{C}$ with $100 \mu \mathrm{Ci}$ of $\left[{ }^{51} \mathrm{Cr}\right.$ ]sodium chromate per $5 \times 10^{5}$ islet cells for $1 \mathrm{~h} .{ }^{51} \mathrm{Cr}$-labeled cells were distributed into 96-well plates at a density of $5 \times 10^{9}$ cells per well. Cells were incubated for $1 \mathrm{~h}$ with a 1:3 dilution of control and test sera at $20^{\circ} \mathrm{C}$, then for another hour with a 1:15 dilution of rabbit serum preadsorbed with rat spleen cells. Each serum was tested in triplicate. $100-\mu$ l aliquots were finally removed from each well and counted in a Packard gammacounter. Maximal chromium release was obtained by incubating $5 \times 10^{3}{ }^{51} \mathrm{Cr}$-labeled cells with $1 \mathrm{ml}$ distilled water for $2 \mathrm{~h}$. The specificity and sentitivity of cytotoxic antibody determination were 90 and 46\%, respectively, in the experimental conditions of the test.

$H L A$ typing. All patients were typed for class II (DR1-DRw10) major histocompatibility complex antigens as previously described (24).

Anti-insulin antibodies (AIA). AIA were determined by immunoprecipitation of ${ }^{125} \mathrm{I}$-labeled insulin (Novo, Copenhagen, Denmark) as previously described $(25,26)$ with slight modifications consisting of a preincubation of tested sera with charcoal. The sensitivity and specificity of the assay were 57 and $100 \%$, respectively, in the experimental conditions used in this study.

Anti-thyroid antibodies. Anti-thyroglobulin and anti-microsomal antibodies were evaluated by a passive hemagglutination test using a commercial kit (Wellcome Diagnostics).

Cyclosporinemia. Cyclosporinemia was evaluated in total blood as a trough level $24 \mathrm{~h}$ after oral intake of the drug using a kit (Sandoz Ltd., Basel, Switzerland).

Expression of data. CF-ICA, ICA, S-ICA, anti-thyroglobulin and anti-microsomal antibody titers were expressed as the $\log _{2}$ value of the last positive dilution of tested sera. AIA were expressed as a percentage of ligand-bound radioactivity. Percentages above $1.9 \%$ (mean +2 SD) were considered positive. Cytotoxic antibodies to beta cells were expressed using the following index: tested serum (cycles per minute)/ maximal release (cycles per minute) $\times 100$. Indexes $>33 \%$ (mean of control sera $+2 \mathrm{SD}$ ) were considered positive. The statistical comparison of antibody titers observed in various groups was performed using the Student's $t$ test.

\section{Results}

ICA (indirect immunofluorescence). At inclusion in the trial S-ICA, ICA, and CF-ICA were detected in 47 (57.3\%), 34 $(41.4 \%)$, and $14(17.1 \%)$, respectively, of all patients, which included $22(55 \%), 16(40 \%)$, and $7(17.5 \%)$ of the placebotreated patients, and $25(59.5 \%), 20(47.6 \%)$, and $7(16.6 \%)$ of the cyclosporin A-treated patients. Initial titers of S-ICA, ICA, and CF-ICA at inclusion in the trial were not significantly different between placebo and cyclosporin A-treated patients (Fig. 1). No significant difference in ICA and S-ICA titers was observed between patients who ultimately showed or did not show remission in both the placebo and the cyclosporin $A$ group (Table I). Within complete remitters there was no statistically significant difference in antibody titers when considering the occurrence of a relapse (transient remission) as compared with the persistence of a stable remission during the follow-up period (data not shown). These data show that ICA positivity has no predictive value for the outcome of the disease in IDDM patients treated with cyclosporin A.

A slow decrease in S-ICA and ICA titers was observed in placebo and cyclosporin-treated patients over a 1-yr follow-up period, but this decrease was not statistically significant in both

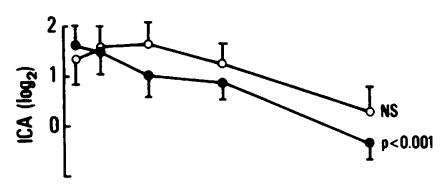

Figure 1. ICA and S-ICA titers in placebo and cyclosporin Atreated patients over a $12-\mathrm{mo}$ follow-up period. The mean value (mean \pm SE) of $(a)$ ICA and $(b)$ S-ICA in placebo (open circles $)(n=16)$ and cyclosporin A (closed circles) ( $n$ =11)-treated patients over the 12 mo follow-up period is represented. Statistical evaluation (NS and $P$ value) is between the mean values at $12 \mathrm{mo}$ as

compared with the mean values at initiation of therapy in each group. There is no significant difference at 1,3 , and 6 mo of treatment. The mean antibody titer is never significantly different between cyclosporin and placebo groups.

groups except when comparing initial and 12th mo ICA titers in cyclosporin-treated patients. The decline was slightly steeper in cyclosporin than in placebo-treated patients, but the difference was not statistically significant between both groups, even at $1 \mathrm{yr}$ when it was the most clear-cut. There was also no significant difference when considering the percentage of patients positive for S-ICA and ICA at 12 mo between the cyclosporin group (56 and $25 \%$, respectively) and the placebo group (50 and $22.7 \%$, respectively).

Within the cyclosporin group, there was no significant difference in the evolution of the mean S-ICA and ICA titer between remitters $(2.00 \pm 0.67 \mathrm{SE}, n=11$, and $0.45 \pm 0.37 \mathrm{SE}, n$ $=11$, respectively, at $12 \mathrm{mo}$ ) and nonremitters $(2.08 \pm 0.71 \mathrm{SE}$, $n=12$, and $0.46 \pm 0.24 \mathrm{SE}, n=12$, respectively, at $12 \mathrm{mo}$ ). Within the placebo group, the occurrence of a relapse in six remitters between the 6th and the 12 th mo of follow-up was never accompanied by a reappearance or increase in S-ICA or CF-ICA titers, nor was this the case in the two patients who relapsed in the cyclosporin group. When individual data are considered in patients who stopped cyclosporin A treatment because of failure, a secondary reappearance of ICA or increase of titers was observed in 4 out of 13 patients by two dilutions (two patients) or three dilutions (two patients) within the six following months. This was never observed in the placebo group (18 patients).

Finally, the evolution of S-ICA and ICA titers did not appear to be clearly dependent on the mean cyclosporinemia level obtained during the first 6 mo of treatment (Table II).

Cytotoxic antibodies. At inclusion in the trial, cytotoxic antibodies to islet cells were observed in 14 (35\%) placebotreated patients and in $19(45.2 \%)$ cyclosporin A-treated patients, again without correlation to ultimate occurrence of remission (data not shown). No close correlation was observed between S-ICA and cytotoxic antibodies. 12 patients had circulating cytotoxic antibodies in the absence of detectable S-ICA while 11 patients had S-ICA in the absence of detectable cytotoxic antibodies. No significant decrease in the mean cytotoxicity index was observed over one year of placebo treatment. A moderate decrease in the mean cytotoxicity index was noted in cyclosporin A-treated patients, but this decrease was not significant until 6 mo after starting treatment and again became nonsignificant at 12 mo. The mean cytotoxicity indexes were never significantly different in cyclosporin and placebo groups over the 12-mo follow-up period (Fig. 2). 
Table I. Relation between the Induction of Remissions Evaluated at 6 mo and Presence or Initial Titer of Cytoplasmic ICA

\begin{tabular}{|c|c|c|c|c|c|}
\hline \multirow[b]{2}{*}{ Remission } & \multirow[b]{2}{*}{ No. patients } & \multicolumn{2}{|l|}{ S-ICA } & \multicolumn{2}{|l|}{ ICA } \\
\hline & & \% Positive & Titer $\left(\log _{2}\right)($ mean \pm SE $)$ & \% Positive & Titer $\left(\log _{2}\right)($ mean $\pm S E)$ \\
\hline \multicolumn{6}{|l|}{ All patients } \\
\hline Complete & 25 & 56 & $3.76 \pm 0.60$ & 40 & $1.4 \pm 0.41$ \\
\hline Complete + partial & 36 & 58.3 & $2.71 \pm 0.48$ & 56 & $1.41 \pm 0.32$ \\
\hline Failure & 46 & 54.3 & $2.36 \pm 0.41$ & 41 & $1.36 \pm 0.32$ \\
\hline \multicolumn{6}{|l|}{ Placebo } \\
\hline Complete & 11 & 45.4 & $2.27 \pm 0.87$ & 36.3 & $1.18 \pm 0.57$ \\
\hline Complete + partial & 13 & 46.1 & $2.15 \pm 0.76$ & 45.4 & $1.08 \pm 0.49$ \\
\hline Failure & 26 & 57.7 & $2.81 \pm 0.58$ & 42 & $1.08 \pm 0.37$ \\
\hline \multicolumn{6}{|l|}{ Cyclosporin } \\
\hline Complete & 14 & 64.3 & $3.43 \pm 0.84$ & 42.8 & $1.64 \pm 0.53$ \\
\hline Complete + partial & 23 & 68.2 & $3.09 \pm 0.57$ & 64 & $1.57 \pm 0.40$ \\
\hline Failure & 20 & 50 & $2.20 \pm 0.56$ & 40 & $0.85 \pm 0.28$ \\
\hline
\end{tabular}

There was no significant difference in the evolution of cytotoxic antibodies depending on cyclosporinemia levels (data not shown).

$A I A$. AIA were detected in $22(55 \%)$ placebo-treated patients and $21(50 \%)$ cyclosporin A-treated patients at inclusion in the trial (which occurred 3-5 wk after initiation of insulin therapy). Follow up showed significantly lower levels of AIA in the cyclosporin A-treated group as compared with the placebo group at both 3 and 6 mo (Fig. 3). Cyclosporin A prevented the production of AIA in patients without detectable antibodies at the initiation of immunosuppressive therapy: the percentage of patients without detectable AIA after 6 mo of cyclosporin treatment $(50 \%)$ was identical to that observed at entry in the trial. In the placebo group, the percentage of patients with detectable AIA rose from $55 \%$ at entry to $87.5 \%$ at $6 \mathrm{mo}$. Additionally, cyclosporin A strongly reduced preexisting AIA production when it was detectable at initiation of therapy. The level of AIA after 6 mo of cyclosporin treatment was lower than that at initiation of therapy in all patients but one. This later patient initially showed an increase in AIA levels from $2.2 \%$ of bound ${ }^{125}$-iodine insulin to $15.1 \%$ at 3 mo of cyclosporin A therapy, then a decrease to $9.2 \%$ at $6 \mathrm{mo}$. Comparatively, in the placebo group, the percentage of bound ${ }^{125}$-iodine insulin at 6 mo was significantly higher than that at entry into the trial in all patients but one, whose level was $1.8 \%$ at $6 \mathrm{mo}$, compared with $1.9 \%$ at initiation of therapy.

When considering only patients who did not stop insulin

Table II. Relationship between the Evolution of Cytoplasmic ICA Titers and the Mean Cyclosporinemia Level over the First 6 mo of Treatment

\begin{tabular}{lcl}
\hline & $\begin{array}{l}\text { Number of } \\
\text { patients }\end{array}$ & $\begin{array}{l}\text { Cyclosporinemia } \\
\text { (mean } \pm \text { SE) }\end{array}$ \\
\hline & & $n g / m l$ \\
Stable S-ICA titer & 18 & $365 \pm 28$ \\
Decreasing S-ICA titer & 7 & $413 \pm 40$ \\
Stable ICA titer & 8 & $396 \pm 47$ \\
Decreasing ICA titer & 12 & $397 \pm 33$
\end{tabular}

injections and were classified as failure at 6 months, the level of AIA was significantly lower at 3 and 6 mo in the cyclosporin A-treated group as compared with the placebo group (Fig. 4). A rebound effect on the production of AIA was observed when treatment with cyclosporin A was stopped at $6 \mathrm{mo}$. The level of AIA was higher at 9 and 12 mo in patients who stopped cyclosporin A treatment (failure) as compared with patients who stopped placebo at $6 \mathrm{mo}$, although this difference did not reach statistical significance (Fig. 4). It is important to stress that the mean daily insulin dose was not significantly different in both groups from the 7 th to the 12th mo $(33 \pm 3 \mathrm{SE}$ and $31 \pm 3 \mathrm{SE} \mathrm{U} / \mathrm{d}$, respectively).

Finally, the occurrence of a relapse in patients in complete remission was never preceded by an increase in AIA (Table III). This precludes any predictive value of AIA in patients in complete remission.

Anti-thyroid antibodies. Eight patients in the cyclosporin A group had circulating anti-microsomal antibodies, compared to three in the placebo group. One of the eight patients in the cyclosporin A group also had anti-thyroglobulin antibodies while another patient had isolated anti-thyroglobulin antibodies. All three patients in the placebo group with antimicrosomal antibodies also had anti-thyroglobulin antibodies. The titer of anti-microsomal antibodies decreased signifi-

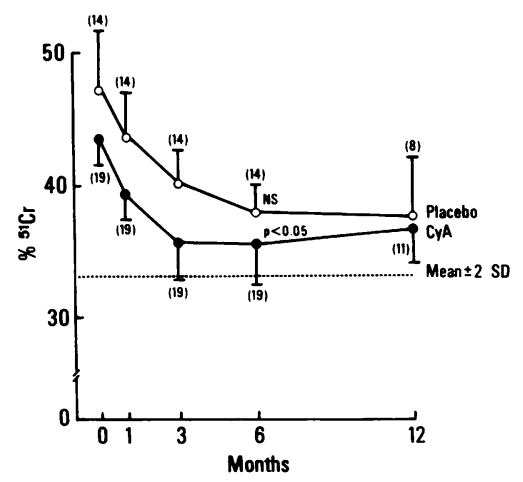

Figure 2. Cytotoxic antibodies in placebo and cyclosporin A-treated patients over a 12 -mo follow-up period. The mean (mean \pm SE) cytotoxicity index in placebo (open circles) and cyclosporin A (CyA) (closed circles)-treated patients is indicated over the 12 mo followup period. Numbers in parentheses indicate the number of tested sera. Statistical evaluation is as in Fig. 1. There is no significant difference at 1,3 , and 12 mo of treatment within each group. 


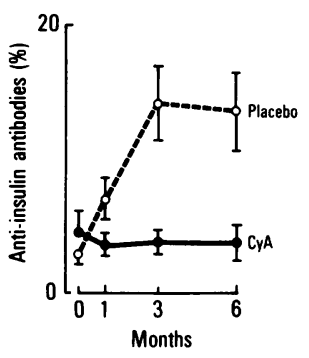

Figure 3. AIA in placebo and cyclosporin A-treated patients over a 6-mo follow-up period. The mean value of the percentage of bound ${ }^{125}$ iodine-insulin in placebo (open circles) $(n=40)$ and cyclosporin A (CyA) (closed circles) $(n=42)$-treated patients is indicated over the 6-mo follow-up period.

cantly after 6 mo of treatment in the cyclosporin A group as opposed to the placebo group (Fig. 5). Although the number of patients with anti-thyroglobulin antibodies is small in both groups, it is worth noting that anti-thyroglobulin antibodies disappeared in one patient, decreased by five $\log _{2}$ dilutions in the other patient under cyclosporin $A$, and remained unmodified or increased by one and two dilutions in the three patients receiving placebo when comparing the 6-mo value to that detected at entry into the trial. Out of the eight patients with detectable anti-microsomal antibodies, six also had cytoplasmic ICA. In these six positive patients, the titer of S-ICA remained unmodified at six months, while anti-microsomal antibodies became undetectable in one, decreased by two dilutions in three, by four dilutions in one, and remained unmodified in one patient.

HLA-DR phenotype. $88 \%$ of treated patients were either HLA-DR3 or DR4. $30 \%$ of patients were both DR 3 and DR4. No significant difference was detected in the titer of ICA, cytotoxic antibodies to islet cells, or AIA in patients of the various DR phenotypes, with the exception of non-DR3, nonDR4 patients, who showed a lower (statistically nonsignificant) incidence of cytoplasmic and cytotoxic anti-islet antibody (Table IV). In addition, since the incidence of remissions was not different in DR3-X, DR4-X, DR3-4, and nonDR3, non-DR4 patients, this preliminary analysis provided no clear evidence that the HLA-DR phenotype allowed any prediction in terms of remission or relapse in clinical remitters.

\section{Discussion}

ICA were detected in $42 \%$ of all patients before starting cyclosporin $\mathrm{A}$ and placebo treatment using the conventional method described by Bottazzo et al. $(8,20)$. With the complement fixation method positivity was even lower (17\%). These figures are below the percentages reported in other series. We have not found such a discrepancy, however, in other groups

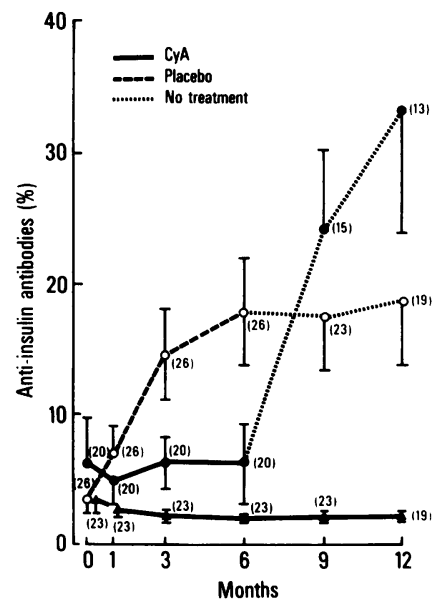

Figure 4. AIA in insulintreated patients over a 12-mo follow-up period. The mean percentage of bound ${ }^{125}$ iodineinsulin in patients who stopped placebo (open circles) and cyclosporin $\mathrm{A}$ (closed circles) treatment at 6 mo and in patients who pursued cyclosporin A treatment (triangles) over a 12-mo period. Numbers in parentheses indicate the number of tested sera.
Table III. Absence of Predictive Value of AIA for Relapse in Patients Showing Complete Remission

\begin{tabular}{lll}
\hline & $\begin{array}{l}\text { Patients studied during } \\
\text { the first months of } \\
\text { remission } \\
\text { (mean } \pm \text { SE) }\end{array}$ & $\begin{array}{l}\text { Patients studied before } \\
\text { relapse* } \\
\text { (mean } \pm \text { SE) }\end{array}$ \\
\hline Placebo $(n=8)$ & $7.2 \pm 2.1$ & $3.6 \pm 0.8$ \\
Cyclosporin A $(n=8)$ & $2.9 \pm 0.2$ & $2.9 \pm 0.1$
\end{tabular}

* Last sample obtained before the occurrence of the relapse.

of diabetic patients, including children or sera studied at the standardization workshop (22). We detected ICA in 58\% of all patients using a sensitized method previously reported by Elliott et al. (21). Figures for cytotoxic antibodies and antithyroid antibodies are consistent with those previously reported in other series $(23,27-29)$. Our results are in accordance with data from the Canadian trial, which indicated that ICA detection is of no value in predicting the therapeutic response to cyclosporin A in IDDM (30). Neither ICA or IAA can be considered as good predictors of relapse in IDDM patients in clinical remission whether or not they are receiving cyclosporin A. Moreover, we observed no correlation between the disappearance of ICA and the induction of clinical remissions. In contrast with data reported from the Canadian open trial (30), we did not find an inverse correlation between the mean ICA titer and the remission rate. Such a discrepancy may be due to differences in the definition of remission criteria.

It is clear from our study that cyclosporin A has only a moderate effect on the titers of both ICA and anti-islet cell cytotoxic antibodies. This finding is consistent with previous data from the canadian cyclosporin A open trial, which indicated an only moderate effect of cyclosporin A therapy on ICA titers in IDDM (30). The absence of correlation between ICA titers and the induction of remission, and the delayed reduction in ICA titer as compared with the onset of remission, suggest that ICA are secondary to rather than responsible for the islet $\beta$-cell destruction. In fact, the absence of an obvious effect of cyclosporin A on anti-islet antibody production contrasted with the clear-cut effect observed in the same patients with $6 \mathrm{mo}$ of cyclosporin therapy (concomitantly with complete remissions) on $T$ cell capacity to inhibit insulin release in vitro (2).

The minor and late reduction of ICA titers in the cyclosporin A group after a 12-mo treatment follow-up may indi-

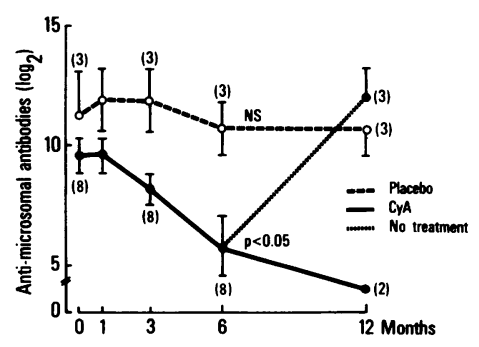

Figure 5. Anti-microsomal antibodies in placebo and cyclosporin A-treated patients. The titers $\left(\log _{2}\right.$ value) are indicated in both placebo (open circles) and cyclosporin A (closed circles)-treated patients over the 12-mo follow-up period. Statistical evaluation is as in Fig. 1. A statistically significant difference is only observed under cyclosporin A treatment after $6 \mathrm{mo}$. ( $\square=$ Indicates the evolution of antibody titres in three patients who stopped cyclosporin A treatment at $6 \mathrm{mo}$. Numbers in parentheses indicate the number of tested sera. 
Table IV. Percentages of Patients with Anti-ICA According to HLA-DR Phenotypes

\begin{tabular}{lllll}
\hline $\begin{array}{l}\text { HLA } \\
\text { marker }\end{array}$ & $\begin{array}{l}\text { No. } \\
\text { patients }\end{array}$ & S-ICA & CF-ICA & $\begin{array}{l}\text { Cytotoxic } \\
\text { antibodies }\end{array}$ \\
\hline & & $\%$ & $\%$ & $\%$ \\
DR3-X & 51 & 68.6 & 17.6 & 43 \\
DR4-X & 43 & 62.7 & 16.2 & 42 \\
DR3/4 & 24 & 70.8 & 12.5 & 50 \\
DRX & 7 & 28.5 & 0 & 28.5 \\
\hline
\end{tabular}

cate either that ICA production is under T lymphocyte control or less likely that ICA production is dependent on cyclosporin A-sensitive B lymphocytes. These hypotheses are interesting in the light of our knowledge of the mechanism of immunosuppressive activity of cyclosporin A. Cyclosporin A mainly inhibits helper $\mathrm{T}$ cells by suppressing interleukin 2 production (31-33), or by suppressing the expression or responsiveness of interleukin 2 receptors $(34,35)$, and as a consequence depresses both cell-mediated immune responses (36) and T-dependent antibody production (37). Whether cyclosporin A has a direct effect on B lymphocytes remains controversial (38-40). Cyclosporin A inhibits some humoral immune responses when given at the time of the antigenic challenge. Conversely, cyclosporin A poorly affects established antibody production by B lymphocytes primed before cyclosporin A administration, as shown by studies of the response to non-self antigens (41). In spontaneous or induced autoimmune diseases in animals, cyclosporin A treatment inhibits autoantibody production when given before rather than after the appearance of autoantibodies, as shown in thyroiditis $(42,43)$ and experimental myasthenia gravis (44). Conversely, cyclosporin shows little or no effect on autoantibody production in experimental uveitis in the rat (45) and in spontaneous thyroiditis in the obese strain chicken (46). The only exception is in lupus mice, where an established anti-DNA autoantibody production has been shown to be inhibited by cyclosporin A (47).

To date, very little is known on the effect of cyclosporin A on autoantibody production in human autoimmune diseases. Disappearance of anti-skin antibodies has been reported in patients suffering from bullous pemphigoid (48). By contrast, no inhibition of anti-double-stranded and antinuclear DNA antibodies has been reported in systemic lupus erythematosus over a 6-mo follow-up period (49). Finally, it is interesting to note that in the responses to exogenous keyhole limpet hemocyanin and tetanus toxoid, cyclosporin A-treated patients with chronic uveitis showed a significant inhibition of delayed-type cutaneous hypersensitivity reactions but no significant reduction of antibody production (50). Conversely, a moderate inhibition of the humoral response to influenza vaccination has been reported in cyclosporin A-treated renal transplant patients (51).

Our data indicate a clearcut difference in the action of cyclosporin A on established anti-islet autoantibody production and the immune response to exogenous insulin. Since the mean duration of insulin therapy was $22 \mathrm{~d}$ before starting cyclosporin A treatment, we assume that AIA were not autoantibodies as may be found in diabetic patients before initiation of insulin therapy, but were antibodies directed at exogenous insulin. Importantly, the decreased level of AIA in patients treated with cyclosporin A was observed independently of the induction of remission. That established AIA produc- tion was strongly inhibited by cyclosporin A treatment is discordant with the differential action of cyclosporin A on antibody production discussed above, depending on its introduction before or after the antigenic challenge. When considering anti-thyroid autoantibody titers, it appears that cyclosporin A also inhibited established anti-thyroid antibody production at variance with the absence of obvious effect observed on antiislet antibody production. This difference may be interpreted as indicating either a different level of autoimmunization against the two organs or a higher involvement of $\mathrm{T}$ cells in thyroiditis as compared with IDDM. The latter hypothesis is unlikely, since anti-islet cell autoantibodies are of the IgG (presumably thymus dependent) isotype.

\section{Acknowledgments}

We thank H. Blondel, H. Cohen, and M. Lecuyer for their excellent technical assistance. We are deeply indebted to Dr. B. Charbonnel, Dr. Du Rostu, Dr. Ph. Passa, Dr. M. Pehuet, Dr. G. Tchobroutsky, and Dr. $P$. Vexiau, who were involved in the Cyclosporin Diabetes French (CDF) study as participating clinicians.

Dr. Castano was supported by INSERM U188, Hopital Saint Vincent de Paul. This work was supported by INSERM, CNRS, and Sandoz Laboratory, Rueil Malmaison, France, as part of the CDF study.

\section{References}

1. Stiller, C. R., J. Dupré, M. Gent, M. R. Jenner, P. A. Keown, A. Laupacis, R. Martell, N. W. Rodger, B. von Graffenried, and B. M. J. Wolfe. 1984. Effects of cyclosporin immunosuppression in insulin-dependent diabetes mellitus of recent onset. Science (Wash. DC). 223:1362-1367.

2. Assan, R., G. Feutren, M. Debray-Sachs, M. C. Quiniou-Debrie, C. Laborie, G. Thomas, L. Chatenoud, and J. F. Bach. 1985. Metabolic and immunological effects of cyclosporin in recently diagnosed type 1 diabetes mellitus. Lancet. i:67-71.

3. Feutren, G., R. Assan, G. Karsenty, H. Du Rostu, J. Sirmai, L. Papoz, B. Vialettes, P. Vexiau, M. Rodier, A. Lallemand, and J. F. Bach. 1986. Cyclosporin increases the rate and length of remissions in insulin-dependent diabetes of recent onset. Results of a multicentre double-blind trial. Lancet. ii:119-124.

4. Laupacis, A., C. R. Stiller, C. Gardell, P. Keown, J. Dupré, A. C. Wallace, and P. Thibert. 1983. Cyclosporin prevents diabetes in BB wistar rats. Lancet. i:10-12.

5. Like, A. A., V. Dirobi, S. Thomas, D. L. Guberski, and A. A. Rossini. 1984. Prevention of diabetes mellitus in the BB/W rat with cyclosporin A. Am. J. Pathol. 117:92-97.

6. Jaworski, M. A., L. Honore, L. D. Jewell, J. G. Mehta, P. McGuire-Clark, J. J. Schouls, and W. Y. Yai. 1986. Cyclosporin prophylaxis induces long-term prevention of diabetes, and inhibits lymphocytic infiltration in multiple target tissues in the high-risk BB rat. Diabetes Res. 3:1-6.

7. Mori, Y., M. Suko, H. Okudaira, I. Matsuba, A. Tsuruoka, A. Sasaki, H. Yokoyama, T. Tanase, T. Shida, M. Nishimura, E. Terada, and Y. Ideda. 1986. Preventive effects of cyclosporin on diabetes in NOD mice. Diabetologia. 29:244-247.

8. Bottazzo, G. F., A. Florin-Christensen, and D. Doniach. 1974. Islet-cell antibodies in diabetes mellitus with autoimmune polyendocrine deficiencies. Lancet. ii:1279-1283.

9. Lendrum, R., G. Walker, A. G. Cudworth, C. Theophanides, D. A. Pyke, A. Bloom, and D. R. Gamble. 1976. Islet cell antibodies in diabetes mellitus. Lancet. ii:1273-1276.

10. Svejgaard, A., P. Platz, and L. P. Ryder. 1980. Insulin dependent diabetes mellitus. Report 8th Int. Histocompatibility Work., Los Angeles. 638-656.

11. Gepts, W. 1965. Pathologic anatomy of the pancreas in juvenile diabetes mellitus. Diabetes. 14:619-633. 
12. Bottazzo, G. F., B. M. Dean, J. M. McNally, E. H. Mackay, P. G. F. Swift, and D. R. Gamble. 1985. In situ characterization of autoimmune phenomena and expression of HLA molecules in the pancreas in diabetic insulitis. $N$. Engl. J. Med. 313:353-360.

13. Sibley, R. K., D. E. R. Sutherland, F. Goetz, and A. F. Michael. 1985. Recurrent diabetes mellitus in the pancreas. Iso- and allograft. Lab. Invest. 53:132-144.

14. Boitard, C., L. M. Chatenoud, and M. Debray-Sachs. 1982. In vitro inhibition of pancreatic B cell function by lymphocytes from diabetics with associated autoimmune diseases: a $\mathrm{T}$ cell phenomenon. J. Immunol. 129:2529-2531.

15. Boitard, C., P. Sai, M. Debray-Sachs, R. Assan, and J. Hamburger. 1983. Anti-pancreatic immunity. In vitro studies of cellular and humoral immune reactions directed toward pancreatic islets. Clin. Exp. Immunol. 55:571-580.

16. Bendtzen, K., T. Mandrup-Poulsen, J. Nerup, J. H. Nielsen, C. A. Dinarello, and M. Svenson. 1986. Cytotoxicity of human pI 7 Interleukin-1 for pancreatic islets of Langerhans. Science (Wash. DC). 232:1545-1547.

17. Mandrup-Poulsen, T., K. Bendtzen, J. Nerup, C. A. Dinarello, M. Svenson, and J. H. Nielsen. 1986. Affinity-purified human interleukin I is cytotoxic to isolated islets of Langerhans. Diabetologia. 29:63-67.

18. Wicker, L. S., J. Miller, and Y. Muller. 1986. Transfer of autoimmune diabetes mellitus with splenocytes from non obese diabetic (NOD) mice. Diabetes. 35:855-860.

19. National Diabetes Data Group. 1979. Classification and diagnosis of diabetes mellitus and other categories of glucose intolerance. Diabetes. 26:1039-1057.

20. Bottazzo, G. F., A. N. Gorsuch, B. M. Dean, A. G. Cudworth, and D. Doniach. 1980. Complement-fixing islet-cell antibodies in type I diabetes; possible monitors of active beta-cell damage. Lancet. i:668-672.

21. Pilcher, C., and R. B. Elliott. 1984. Improved sensitivity of islet cell cytoplasmic antibody assay in diabetics. Lancet. i:1352.

22. Bottazzo, G. F., and H. Gleichmann. 1986. Immunology and diabetes workshops: report of the first international workshop on the standardization of cytoplasmic islet cell antibodies. Diabetologia. 29:125-126.

23. Dobersen, M. J., J. E. Scharff, F. Ginsberg-Fellner, and A. L. Notkins. 1980. Cytotoxic autoantibodies to beta cells in the serum of patients with insulin-dependent diabetes mellitus. N. Engl. J. Med. 303:1493-1498.

24. Deschamps, I., H. Lestradet, C. Bonaïti, M. Schmid, M. Busson, A. Benajam, A. Marcelli-Barge, and J. Hors. 1980. HLA genotype studies in juvenile insulin-dependent diabetes. Diabetologia. 19:189193.

25. Kurtz, A. B., J. A. Matthews, B. E. Mustaffa, P. R. Daggett, and J. D. N. Nabarro. 1980. Decrease of antibodies to insulin, proinsulin and contaminating hormones after changing treatment from conventional beef to purified pork insulin. Diabetologia. 18:147-150.

26. Palmer, J., C. M. Asplin, P. Clemons, K. Lyen, O. Tatpati, P. K. Raghu, and T. L. Paquette. 1983. Insulin antibodies in insulin-dependent diabetics before insulin treatment. Science (Wash. DC). 222:1337-1339.

27. Nerup, J., and C. Binder. 1973. Thyroid, gastric and adrenal autoimmunity in diabetes mellitus. Acta Endocrinol. 72:279-286.

28. MacCuish, A. C., and W. J. Irvine. 1975. Autoimmunological aspects of diabetes mellitus. Clin. Endocrinol. Metab. 4:435-471.

29. Riley, W. J., P. P. Toskes, N. K. MacLaren, and J. H. Silverstein. 1982. Predictive value of gastric parietal cell autoantibodies as a marker for gastric and hematologic abnormalities associated with insulin-dependent diabetes. Diabetes. 31:1051-1055.

30. Mandrup-Poulsen, T., J. Nerup, C. R. Stiller, B. Marner, G. Bille, R. Martell, D. Heinrichs, J. Dupre, P. A. Keown, M. R. Jenner, N. W. Rodger, B. Wolfe, B. von Graffenried, and C. Binder. 1985. Disappearance and reappearance of islet cell cytoplasmic antibodies in cyclosporin-treated insulin-dependent diabetics. Lancet. i:599-602.

31. Palacios, R. 1982. Concanavalin A triggers T lymphocytes by directly interacting with their receptors for activation. J. Immunol. 126:337-342.

32. Dos Reis, G. A., and E. M. Shevach. 1982. Effect of cyclosporin $A$ on $T$ cell function in vitro: the mechanism of suppression of $T$ cell proliferation depends on the nature of the $\mathrm{T}$ cell stimulus as well as the differentiation state of the responding T cell. J. Immunol. 129:2360 2362.

33. Bunjes, D., C. Hardt, M. Röllinghoff, and H. Wagner. 1981. Cyclosporin A mediates immunosuppression of primary cytotoxic $\mathrm{T}$ cell responses by impairing the release of interleukin 1 and interleukin 2. Eur. J. Immunol. 11:657-661.

34. Larsson, E. L. 1980. Cyclosporin A and dexamethasone suppress $\mathrm{T}$ cell responses by selectively acting at distinct sites of the triggering process. J. Immunol. 124:2828-2892.

35. Lillehoj, H. S., T. R. Malek, and E. M. Shevach. 1984. Differential effect of cyclosporin $A$ on the expression of $\mathrm{T}$ and $\mathrm{B}$ lymphocyte activation antigens. J. Immunol. 133:244-250.

36. Borel, J. F., C. Feurer, C. Magnée, and H. Stähelin. 1977. Effects of the new anti-lymphocytic peptide cyclosporin A in animals. Immunology. 32:1017-1025.

37. Borel, J. F., C. Feurer, H. V. Gubler, and H. Stähelin. 1976. Biological effects of cyclosporin A: a new anti-lymphocytic agent. Agents Actions. 6:468-475.

38. Dongworth, D. W., and G. G. B. Klaus. 1982. Effects of cyclosporin $A$ on the immune system of the mouse. I. Evidence for a direct selective effect of cyclosporin A on B cells responding to anti-immunoglobulin antibodies. Eur. J. Immunol. 12:1018-1022.

39. Muraguchi, A., J. L. Butler, J. H. Kehrl, R. J. M. Falkoff, and A. S. Fauci. 1983. Selective suppression of an early step in human B cell activation by cyclosporin A. J. Exp. Med. 158:690-702.

40. Klaus, G. G. B., and C. M. Hawrylowicz. 1984. Activation and proliferation signals in mouse B cells. II. Evidence for activation (G0 to G1) signals differing in sensitivity to cyclosporin. Eur. J. Immunol. 14:250-254.

41. Kunkl, A., and G. G. B. Klaus. 1980. Selective effects of cyclosporin A on functional B cell subsets in the mouse. J. Immunol. 125:2526-2531.

42. McGregor, A. M., D. P. Rennie, A. P. Weetman, R. A. Hassman, S. M. Foord, C. Dieguez, and R. Hall. 1983. The influence of cyclosporin A on experimental autoimmune thyroid disease in the rat. Life Sci. 32:97-108.

43. Vladutiu, A. O. Effect of cyclosporine on experimental autoimmune thyroiditis in mice. Transplantation. 35:518-520.

44. Drachman, D. B., R. N. Adams, K. McIntosh, and A. Pestronk. 1985. Treatment of experimental myasthenia gravis with Cyclosporin A. Clin. Exp. Immunol. Immunopathol. 34:174-188.

45. Nussenblatt, R. B., M. M. Rodrigues, W. B. Wacker, S. J. Cevario, M. C. Salinas-Carmona, and I. Gery. 1981. Cyclosporin A. Inhibition of experimental autoimmune uveitis in Lewis rats. J. Clin. Invest. 67:1228-1231.

46. Wick, G., P. U. Müller, and S. Schwarz. Effect of cyclosporin A on spontaneous autoimmune thyroiditis of Obese strain (OS) chickens. Eur. J. Immunol. 12:877-881.

47. Jones, M. G., G. Harris, and G. Cowing. 1983. Response of murine autoimmune disease to cyclosporine and thiols. Transplant. Proc. 15:2904-2908.

48. Thivolet, J., H. Barthelemy, G. Rigot-Muller, and A. Bendelac. 1985. Effects of cyclosporin on bullous pemphigoid and pemphigus. Lancet. i:334-335.

49. Feutren, G., S. Quérin, F. Tron, L. H. Noel, L. Chatenoud, Ph. Lesavre, and J. F. Bach. 1986. The effects of cyclosporine in patients with systemic lupus. Transplant. Proc. 18:643-644.

50. Palestine, A. G., F. Roberge, B. L. Charous, H. C. Lane, A. S. Fauci, and R. B. Nussenblatt. 1985. The effect of cyclosporine on immunization with tetanus and keyhole limpet hemocyanin $(\mathrm{KLH})$ in humans. J. Clin. Immunol. 5:115-121.

51. Versluis, D. J., W. E. P. Beyer, N. Masurel, G. J. Wenting, and W. Weimar. 1986. Impairment of the immune response to influenza vaccination in renal transplant recipients by cyclosporin, but not azathioprine. Transplantation. 42:376-379. 